\title{
Writing the Etfinic Origins of the Rasulids in Late Medieval South Arabia
}

\author{
Daniel Mafioney*
}

The Rasulids arrived in South Arabia towards the end of the sixth/twelfth century as Turkoman officers in the Ayyubid military. Thereafter they established a dynasty that lasted until the mid-ninth/fifteenth century. At the height of their power at the end of the seventh/thirteenth century, an effort to further buoy their political legitimacy was undertaken by resituating their ethnic origins to South Arabia. This first appeared within a genealogy that simultaneously showed their emergence from the complex web of descent of the local tribes, as well as juxtaposed them with the rulers of the Islamic Caliphate and elevated them above other contemporary political groups in South Arabia. However, after the Rasulid military was increasingly challenged over the course of the eighth/fourteenth century and the dynasty's influence in the region and the wider Islamic world continued to dissipate, the assertion of their local origins was greatly fleshed out into a narrative at the beginning of a dynastic chronicle of the early ninth/fifteenth century. This prologue explains more explicitly how they first emigrated from South Arabia in the pre-Islamic period only to then return in the late medieval period as its rightful rulers. Overall, the construction of this origin story points to the Rasulids' attempt to take on a new strategy of identification through the appropriation of South Arabian cultural memory in order to strengthen their political status.

* Austrian Academy of Sciences, Institute for Social Anthropology, Hollandstrasse 11-13, 2.0 floor, 1020, Vienna, Austria.

E-mail: daniel.mahoney@oeaw.ac.at

The Medieval History Journal, 21,2 (2018): 380-399

SAGE Publications LosAngeles/London/NewDelfii/Singapore/WasfingtonDC/Mel6ourne DOI: $10.1177 / 0971945818775459$ 


\section{Introduction}

As Șalāḥ al-Dīn Yūsuf b. Ayyūb was consolidating his power in Egypt during the second half of the sixth/twelfth century, his brother Turānshāh explored alternative regions nearby to which to expand and exploit. ${ }^{1}$ His first campaign was to Nubia, but he then began to focus on South Arabia due to the massive amount of potential income to be extracted through taxation on its fertile interior and the frequent commerce occurring along its coastline as ships passed between the Indian Ocean and the Red Sea. ${ }^{2}$ Subsequently, he undertook a military expedition in 569/1173, which first landed on the northern Red Sea coast of South Arabia, continued along its coastal plain to Aden and then pushed into the highlands until Sanaa. In its path, this campaign led to the dissolution of a number of local dynasties and laid the foundations for the Ayyubids to set up their turbulent rule of the region. Rising among the ranks of the Ayyubid military during this occupation was a family of officers named the Rasulids (Banū Rasūl), including initially the father Shams al-Dīn 'Alī b. Rasūl and his four sons Badr al-Dīn Hasan, Nūr al-Dīn 'Umar, Fakhr al-Dīn Abū Bakr and Sharaf al-Dīn Mūsā. As a result, when the Ayyubid Sultan of South Arabia al-Mas' $\bar{u} d$ departed for a new appointment in Syria in 626/1228, he left Rasulid Nūr al-Dīn 'Umar in charge until the next Ayyubid sultan arrived. Al-Mas' $\bar{u} d$, however, died on his way north and an Ayyubid replacement never came. At first, Nūr al-Dīn 'Umar kept an outward appearance of loyalty to the Ayyubids, but slowly he began to consolidate his power in South Arabia and expressed his own autonomy. He took over important forts and made a truce with the Zaydis to the north. He also married the wife of the late al-Mas' $\bar{u} d$ and minted coins with his name. Then, in 632/1234, Nūr al-Dīn 'Umar received an official certificate of recognition of his sovereignty from the Abbasid Caliph al-Mustanșir in Baghdad and began to use the title of sultan. Over the course of the next six decades he and then his son al-Muzaffar Yūsuf exerted Rasulid influence in most of South Arabia through aggressive military action against the dispersed tribal and Zaydi groups.

\footnotetext{
${ }^{1}$ Centuries and dates in this article are given in the format of $\mathrm{AH} / \mathrm{AD}$.

${ }^{2}$ Additional motivations for the Ayyubids to conquer South Arabia include the search for a place of political refuge and the pleas of the Yemeni historian 'Umāra to save South Arabia from the local antagonistic dynasty of the Mahdids (Smith, The Ayyübids and Early Rasülids in the Yemen, vol. 2: 31-35).
} 
While the Ayyubids themselves were a Kurdish dynasty, the military that accompanied the Ayyubids in their expeditions to South Arabia had mostly Turkoman and Kurdish origins. Collectively, these soldiers were denoted by Arab authors as ghuzz, referring originally to the Turkish Oghuz groups who arrived to the Near East from Central Asia. This vague ethnic descriptor for these soldiers appears in various texts of the late medieval period of South Arabia after the Ayyubid invasion. ${ }^{3}$ For example, there is a notice about a ghuzz shield in a seventh/thirteenthcentury administrative document. ${ }^{4}$ But more prominently this term often appears in historiographic works, such as in the title of an early Rasulid chronicle that explicitly describes the Ayyubid and first two Rasulid rulers as ghuzz kings (mulük). ${ }^{5}$ While the use of this ethnic term obfuscates a more specific determination of the origins for these foreign soldiers, it is clear that it is used by Arab authors to underscore their non-Arab origins. ${ }^{6}$

Despite, or perhaps because of, this perception of the Rasulids as foreigners, at the height of their power at the end of the reign of Sultan al-Muzaffar Yūsuf, his son al-Ashraf 'Umar created a genealogical work that interweaves the family into a web of descent through which the local tribes of South Arabia conceptually organised themselves. ${ }^{7}$ In Turfat al-așhāb fi ma'rifat al-ansāb, the Rasulids are presented as descending from a specific group of tribes of pre-Islamic South Arabia within the confederation of Kahlān. Hence, with this genealogy al-Ashraf 'Umar took on this aspect of Yemeni cultural memory in order to redefine the Rasulids' previous outsider status and repurposed it for their own political needs of legitimacy. Through his manipulation of the tool of genealogy

\footnotetext{
${ }^{3}$ There is, however, an earlier appearance of the term ' $g h u z z$ ' in a twelfth-century chronicle from South Arabia, in which they are described to have been invited by a local ruler to act as mercenaries against another local dynasty ('Umāra, Tārīkh al-Yaman: 77).

${ }^{4}$ Anonymous, Nūr al-má ārif, vol. 2: 57.

${ }^{5}$ Ibn Ḥātim, Kitāb al-simt al-ghā̄l̄ al-thaman fì akhbār al-mulūk min al-ghuzz bi-l-Yaman. This thirteenth-century chronicle was the first to narrate the reigns of the Ayyubid and early Rasulid sultans.

${ }^{6}$ In medieval chronicles from South Arabia, references to specifically Turkish (atrāk) and Kurdish $(a k r \bar{a} d)$ individuals and groups are fairly rare. For a discussion of their interplay with individuals and groups specifically described as Arab ('arab), see: Mahoney, 'Political Agency of Kurds'.

${ }^{7}$ The best presentation of the components of the tribal community of South Arabia in the medieval period is found in the work of $a l-I k l \bar{l} l$, written by a local tribal scholar, Abū Muhammad al-Ḥassan al-Hamdān̄i, in the first half of the tenth century.
}

- The Medieval History Journal, 21, 2 (2018): 380-399 
to create closer bonds of collective identity with the local population, instead of their otherwise apparent exclusion from it, al-Ashraf 'Umar initiated a new process of cultural memory formation in order integrate the Rasulids into the greater ethno-political identity of the South Arabian tribal community. ${ }^{8}$

This appropriation of cultural memory of the inhabitants of South Arabia becomes even more distinct a century later in the prologue of the Rasulid dynastic chronicle $A l^{-}{ }^{`} U q \bar{u} d$ al-lu'lu'iyya fì tārīkh al-dawla alRasüliyya. ${ }^{9}$ Writing in the service of Sultan al-Ashraf Ismā'īl, its author, al-Khazrajī, built upon the retooled genealogical ideas of his predecessor and fleshed out a more straightforward and elaborate narrative of Rasulid origins. Initiated by the fateful breaking of the Ma'rib dam in the desert of South Arabia, it narrates the subsequent mass exodus of tribes to other parts of the Arabian Peninsula and beyond. Political dynasties from across the Islamic world have similarly connected origin stories. ${ }^{10}$

\footnotetext{
${ }^{8}$ Jan Assmann speaks about this process of foreign conquerors integrating into their newly dominated realms through cultural assimilation (Assmann, Cultural Memory: 131). However, in this case the Rasulids do not seem to have fully assimilated into South Arabian culture but rather have mainly used its symbolic tools to artificially insert themselves within it. In this way perhaps it is better understood as cultural appropriation for political aims rather than assimilation. At the same time, the genealogies of Arabia routinely were reconstructed for political means in the medieval period (Szombathy, The Roots of Arabic Genealogy).

${ }^{9}$ Most of this historiographic work is a section from two longer universal chronicles also attributed to al-Khazrajī (with the close involvement of Rasulid Sultan al-Ashraf Ismā̄îl): Al-'Asjad al-masbūk fì sīrat/akhbār al-khulafä’’ wa-l-mulūk and Al-Kifāya wa-l-i'lām fì man waliya al-yaman wa-sakanahä fi al-isläm. There is some confusion regarding the differences and relationship between these two histories. The medieval historian al-Maqrīzī states that $A l$ - $^{\prime}$ Asjad al-masbūk is structured according to year, while Al-Kifäya is organised by reign. This difference, however, may be due to Al-'Asjad al-masbük consisting of two volumes with the former organised by year and latter organised by reign (Vallet, 'L'historiographie rasūlide': 63-66). Another way the two have been described is that Al-'Asjad al-masbūk comprises a longer history of the Islamic world, while Al-Kifäya merely consists of the final two chapters of $\mathrm{Al}_{-}{ }^{\mathrm{C}}$ Asjad al-masbük that focus on the rulers of Sanaa, Aden and Zabid (Bates, Yemen and Its Conquest: 23-25).

${ }^{10}$ For example, there are claims in the medieval period that certain Berber groups descend from Yemeni Himyarī origin (Shatzmiller, Berbers and the Islamic State: 17-27) or that the origins of the Daylamites extend from an Arab tribe which migrated into the region in an early period (Baker, 'Lost Origins of the Daylamites': 284-85). Similarly, a ninth/ fifteenth-century treatise presented to the Mamluk Sultan al-Mālik al-Zahir Tatar states that his Circassian roots partly descend from the South Arabian tribal group of the Ghassanids
} 
But unlike the ending of these other tales, in which a wandering tribe becomes a foundational building block for a dynasty in a new area of the Islamic world, the Rasulids instead return to South Arabia as both its rightful rulers and its long-lost brethren. Thus, this circular migration brings an added component to this origins formula which engenders and mixes ideas of political legitimacy and filial affinity in order to make a compound ideological statement to support the flagging Rasulids at the turn of the ninth/fifteenth century. At this point in time, although a prominent court culture continued to exist at both of the capitals of Ta'izz and Zabīd, the territory and authority of the Rasulids within South Arabia was much reduced from what it had been a century before, and they were facing continual tribal rebellions across the region. Thus, as an introduction to his celebratory dynastic chronicle, al-Khazrajī rewrote this common Islamic historiographic origin story with the insertion of the Rasulids in order to reaffirm and bolster their political identity as the true rulers of South Arabia. Ultimately, through the revision of this narrative, al-Khazrajī reorganised the past to match and support what he wished the current political situation to be. For the rest of this article, I will dive more deeply into both of these works in order to better explicate and understand how these two Rasulid historians took ideas from both the Yemeni and wider Islamic historiographic traditions about the preIslamic South Arabian past in order to establish a new ethnic identity for the Rasulids that both integrated them into and elevated them above the region's political landscape.

\section{The Genealogy}

Al-Ashraf 'Umar compiled Țurfat al-așhāb fì ma'rifat al-ansāb shortly before he succeeded his father al-Muzaffar as sultan in 694/1295. It consists of an abbreviated synthesis of genealogies that extend from ancient patriarchal lineages to the Rasulid dynasty and its political contemporaries in South Arabia. In between, there is a condensed summary of the genealogical ties that structure the tribes of South Arabia as well as the genealogy of Prophet Muhammad and the succeeding caliphs,

(Iliushina, 'Origins of the Circassian Mamluks': 5-6). Ultimately, the breaking of the Ma 'rib dam is alluded to in the Qurān (34:15-16).

- The Medieval History Journal, 21, 2 (2018): 380-399 
including the rulers of both the Umayyad and Abbasid dynasties. He describes its contents as follows:

This is an abridged account of genealogy. Its memorization is easy for those of intelligence. Containing the origins of the lineages of the Arabs, it makes more accessible their memorization for those who wish to know them. Added to it is the lineage of the chosen Prophet, accompanied by his pious companions. We pointed out those who had the strongest bonds with him and those who were closest to him in kinship. Then we followed with the caliphs of the Umayyads and Abbasids, the Rasulid kings of Yemen, and those who were noted for their service from the elite of the ashrāf in our time and the Arabs. ${ }^{11}$

From the beginning al-Ashraf 'Umar makes the political intent of his genealogical work clear: first establishing the pedigree of the Rasulids among the Yemeni tribes, then juxtaposing them against the development of the caliphate and finally describing those within South Arabia whom they perceive to serve under them. But his work is also a carefully crafted and considered scholarly study following in the tradition of the sultans of the Rasulid dynasty who took an active part in intellectual and cultural production. ${ }^{12}$ Throughout the genealogy al-Ashraf ${ }^{\prime}$ Umar makes comments that demonstrate his desire to underline the investigation and argumentation that led to the conclusions of his work. In the final sentence of Turfat al-așhāb, he succinctly sums up and emphasises this process by stating: 'So this is what the research communicated. God knows best'. In this genealogy, al-Ashraf 'Umar cites for varying reasons different authors from the South Arabian (e.g., al-Hamdānīis and Nashwān b. Sa ${ }^{c} \overline{1} d$ al-Hịmyarîn $\left.{ }^{14}\right)$ and wider Islamic historiographic

${ }^{11} \mathrm{Al}$-Ashraf 'Umar, Turfat al-așhāb: 1-2. Here the 'ashräf" refer to different Zaydi groups living mainly in the northern Yemeni highlands, while the 'Arabs' refer to the Arab tribes dispersed across South Arabia.

${ }^{12}$ This includes, for example, Sultan al-Muzaffar's manual about craft production (Almukhtara' fi funūn al-suna') and Sultan al-Afdal al-'Abbas's close relation to the creation of the so-called Rasulid Hexaglot - a glossary of six matching vocabularies from across Eurasia (Golden, Halasi-Kun, Ligeti, and Schütz, The King's Dictionary).

${ }^{13} \mathrm{Al}$-Ashraf 'Umar, Turfat al-așhāb: 8, 43, 57. The first is about the unique relationship between the tribes of Alhān and Hamdān, the second is about the length of Himyar's reign and the third is a genealogical entry on Khawlān al-'Āliya as cited in the tenth volume of al-Iklīl.

${ }^{14} \mathrm{Al}$-Ashraf 'Umar, Turfat al-așhāb: 43. This citation focuses on the chain of rulership in ancient South Arabia from al-Hamaysa ${ }^{c} b$. Himyar until the arrival of a delegation led by 'Abd al-Muțāāib. 
traditions (e.g., Ibn Wāḍih al-Ya qūbī ${ }^{15}$ Ibn al-Athīr, ${ }^{16}{ }^{1 b n}$ al-Ash ${ }^{c} a r{ }^{17}$ and al-Tabar $\left.\overline{1}^{-18}\right)$. Additionally, he adduces the Kitāb bulghat al-zurafä $f i$ ta'rīkh al-khulafä for the sections regarding the Umayyad and Abbasid Caliphs ${ }^{19}$ and repeatedly refers to another of his works, entitled Jawähir al-Tijān, which appears to contain narratives of events relating to persons mentioned in the genealogy. ${ }^{20}$

This carefully curated research resulted in a deliberately structured genealogy aiming to show that the descent of the Rasulids extends from a specific part of the tribal community of South Arabia, which left after the breaking of the Ma rib dam rather than those who remained behind. ${ }^{21}$ At first, al-Ashraf 'Umar sets a broad foundation for the genealogy, which extends from the patriarchal figures of Ādam (Adam) and his children, as well as Nūḥ (Noah), Sām (Shem) and Ḥām (Ham) through various groups of ancient Arabs (al-'arab al-muta'arriba, al-'arab al-'arba ${ }^{\prime}$ and $a l$-' $^{\prime} a r a b$ $a l-\bar{a} r i b a)$ that lead to the forefathers of the Arabs of the South (Qahțān) and North ('Adnān) and their descendants (e.g., Hamdān, Madhhiji, Qays and Rabīa). After this point in the genealogy, al-Ashraf 'Umar begins to review the ancient lineages in an order from those closest to the Rasulids to those furthest away in three major groupings (respectively, Kahlān, Himyar and 'Adnān). Even in the first section, focused on descendants of Kahlān, he prudently organises his tribal descriptions and periodically punctuates them with direct comments to emphasise how exactly the

${ }^{15} \mathrm{Al}$-Ashraf 'Umar, Turfat al-așhāb: 2. This is in reference to the patriarchal genealogy beginning with Ādam until the sons of Sām, Ḥām and Yāfith.

${ }^{16} \mathrm{Al}$-Ashraf 'Umar, Turfat al-așhāb: 3, 5. The first refers to the descendant of Ḥām and Sām, and the second describes the different categories of al-'arab al-muta'arriba, al-'arab

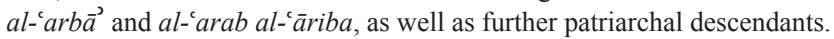

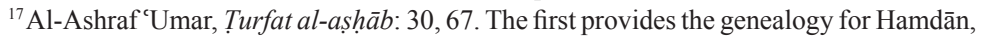
and the second gives a genealogy for 'Adnān.

${ }^{18} \mathrm{Al}$-Ashraf 'Umar, Turfat al-așhāb: 67. This citation provides an alternative genealogy for 'Adnān (in comparison to the one given by Ibn al-Ash'arī).

${ }^{19} \mathrm{Al}$-Ashraf 'Umar, Turfat al-așhāab: 77, 81.

${ }^{20} \mathrm{Al}$-Ashraf ${ }^{\mathrm{C}} \mathrm{Umar}$, Țurfat al-așhāb: 20, 45, 47. They refer to stories about such figures from pre-Islamic South Arabia history as 'Amr b. 'Āmir Muzayqiyā', Abraha and Dhū Nuwas.

${ }^{21}$ There are also brief indications in the text that al-Ashraf 'Umar is actively responding to and correcting poets who do not give an accurate lineage for the Rasulids from within the tribes of South Arabia (Al-Ashraf 'Umar, Turfat al-așhāb: 26, 42). Vallet emphasizes this point, indicating the high importance of poetry as a political instrument in medieval South Arabia and the counter-effects it may bring about if it disseminates incorrect or confused information (Vallet, 'L'historiographie rasūlide': 41-42).

- The Medieval History Journal, 21, 2 (2018): 380-399 
Rasulids fit into its lineages. ${ }^{22}$ For example, as he begins to delineate the tribal groups descending from Qahtān, after mentioning Saba' as the father of Himyar and Kahlān, he goes on to name al-Azd as the progenitor of the Rasulids. ${ }^{23}$ Then later on the Rasulids are again specifically mentioned as descending from the offspring of Jabala b. al-Ayham of the Banū Jafna of the Ghassanids. ${ }^{24}$ In the latter reference, al-Ashraf 'Umar goes as far as to precisely stipulate the Rasulids' variously graded relation to other distinguished descendants of Qaḥtān, notably the Himyarite kings (via Himyar b. Qaḥtạn) and the Lakhmid kings of al-Hīra (via Lakhm b. Kahlān b. Qaḥ̣̂ān).

Whoever traces back the lineage of the kings of the Banū al-Rasūl, in poetry or something else, to the kings of Himyar or to the tabābic $a, a q y \bar{a} l$ and $a d h w \bar{a}$, or to the kings of Banū al-Mundhir, like 'Amr b. Hind and al-Nu'mān and others who are from Lakhm, then that like saying a man genealogically relates to his cousins. But the Lakhmid Banū al-Mundhir are the closer in degree, than the kings of Himyar, to the Banū al-Rasūl. ${ }^{25}$

Alongside an emphasis on the nuances of genealogical descent, this quote also refers to a second concomitant theme in Turfat al-Așhāb that focuses on the succession of kingship (mulk) in its various strands, such as the dynasties of the Lakhmids, Himyarites and Jafnids. For the most part, in this work there are only passing references to events that surround the individuals and groups in the genealogy, such as brief mentions of the construction and breaking of the Ma'rib dam and subsequent exodus of tribes. ${ }^{26}$ But there are sections that delineate the passing of rulership from one group or person to the next. Within the description of the Kahlān genealogy, there is a loose narrative of kingship passing through various people as they migrate across the peninsula, but there are also specific statements relating directly to the Rasulids. At one point the forefathers of the kings of the Banū Rasūl are stated to be from the pre-Islamic kings of al-Azd from South Arabia, including:

${ }^{22}$ Al-Ashraf 'Umar, Țurfat al-așhāb: 39.

${ }^{23}$ Ibid: : 19-20.

${ }^{24}$ Ibid.: 25.

${ }^{25}$ Ibid.: 26.

${ }^{26}$ Ibid.: 19-20. The small amount of these stories is most likely due to some of them being described in al-Ashraf's other work or because they are familiar from other previous or contemporary historiographic work. 
'Amr b. 'Āmir Muzayqiyā', his father 'Āmir Mā' al-Samā', Ḥāritha alGhiṭīif, Imru' al-Qays al-Bitrīq and Tha laba al-Buhlūl. ${ }^{27}$ Furthermore, the Rasulid kings are also said to have descended from the Jafnid kings of al-Shām (Syria). Al-Ashraf 'Umar is not subtle with the ideological significance of this relationship. After he specifically names the Rasulid sultans of al-Manșūr 'Umar and al-Muzaffar Yūsuf as well as himself, as descending from the Jafnid kings, he describes the Rasulids as 'the best kings of Yemen, the best kings of the period, and the foremost among the people who lived at that time' ${ }^{28}$

This descent of kingship for the Rasulids is then mirrored in the next genealogical section of Turfat al-Așhāb that focuses on the lineages from Himyar. Here a long entry provides a concise recounting of the development of kingship within South Arabia, beginning with Saba' who is stated to have built the Ma rib dam. ${ }^{29}$ This narration begins in a laudatory mode of the accomplishments of the region's ancient kings but goes on to describe the loss of local sovereignty due to the takeover of kings from Ethiopia (al-Habasha) and the local Yemenis' subsequent seeking of help from Persia until the arrival of a delegation led by 'Abd al-Muțalib, grandfather of Prophet Muhammad. Thus, while much of the Himyar section of the genealogy highlights the achievements of various ancient rulers of South Arabia, al-Ashraf subliminally parallels the demise of its rulership under the Himyarties against the continual strength of the al-Azd/ Ghassanid line of kingship, which eventually returns to South Arabia with the arrival of the Rasulids. This important distinction elucidates al-Ashraf 'Umar's repeated insistence that the Rasulids descend from the Kahlān and not the Himyar branch of the South Arabian tribal community.

The final section of the ancient genealogy focuses on the descendants of the forefather of North Arabia ('Adnān). Here the merging of genealogy and rightful rulership quickly becomes clear as the lineage's descendants are shown to include the tribe of Muhammad (Quraysh) and then the prophet himself. Al-Ashraf 'Umar moves on to describe with minimal comments the companions and successors of the prophet, including the caliphs of the Umayyads and Abbasids ending with the contemporary Caliph al-Musta'șim. From here he abruptly returns the focus to the

${ }^{27}$ Al-Ashraf 'Umar, Țurfat al-așhāb: 42.

${ }^{28}$ Ibid.: 27-28.

${ }^{29}$ Ibid.: $43-48$.

- The Medieval History Journal, 21, 2 (2018): 380-399 
Rasulids by providing the first full description of their lineage from the grandfather of al-Ashraf 'Umar to Kahlān, son of Saba'.

Shams al-Dīn 'Alī, son of Rasūl, son of Hārūn, son of Abū al-Fatḥ al-Jafnī al-Ghassānī from the offspring of Jabala, son of Ayham, son of Jabala, son of al-H̄ārith, son of Abī Jabala, son of al-Ḥārith, son of Tha' laba, son of 'Amr, son of Jafna, son of 'Amr Muzayqiyā', son of 'Āmir Mă' al-Samā', son of Hiaritha al-Ghițrīf, son of Imru' al-Qays al-Buhlūl, son of Tha'laba al-Bitrīq called al-'Anqā', son of Māzin Zād al-Safar, son of al-Azd, son of al-Ghawth, son of al-Nabt, son of Mālik, son of Zayd, son of Kahlān. ${ }^{30}$

The direct juxtaposition of this genealogy against that of the caliphate seems to reflect a two-fold sense of legitimacy. First, it indicates an implicit reminder that the caliphate has granted its approval of the Rasulids as the rulers of South Arabia, stemming from the original decree of alMustanșir in 632/1234, and therefore the Abbasids, at least textually, stand beside them in support. Second, it concisely dictates the deeply rooted relationship that the Rasulids have to the tribal community of South Arabia as emanating from the kings of al-Azd and their predecessors. Moreover, to reinforce and make their precise belonging to it even more apparent, al-Ashraf 'Umar next recites a dialogue about the major figures of the Rasulid lineage.

If one of them were asked: from which of the tribes are you? Then he would answer that he is from Qahțān. [If] it were said to him: from which of Qahțān? Then he would say: from Kahlān. And [if] it were said: from which of Kahlān? Then he would say: from al-Azd. And [if] it were said: from which of al-Azd? He would say: from Ghassān. And [if] it were said: from which of Ghassān? He would say: from Jafna. And [if] it were said: from which of Jafna? He would say: from the descendants of Jabala b. al-Ayham. ${ }^{31}$

This passage is evidently intended to act as a direct strategy of identification through its inclusion of the Rasulids' most prominent forefathers as they extend across the peninsula: Qaḥțān, Kahlān, al-Azd, Ghassan, Jafna and

${ }^{30}$ Ibid.: 89. It is interesting to note that despite the names 'Tha' laba al-Buhlūl' and 'Imru' al-Qays al-Bitrīq' being stated previously in this text and in the genealogy of the next text below, here the final parts of the names are switched as 'Imru' al-Qays al-Buhlūl' and 'Tha'laba al-Bitrīq'.

${ }^{31} \mathrm{Al}$-Ashraf 'Umar, Țurfat al-aṣhāo: 89. 
Jabal b. al-Ayham. Thus, building upon all of the previously provided genealogical information, these simple statements communicate the Rasulids' asserted 'correct' ethnic origins in order to support their rule over all of South Arabia. In the remaining sections of the genealogy, alAshraf 'Umar provides limited information about the lineages for other political groups within the region, which are described as their servants but many of whom would have been their political rivals: the Zaydi ashräf, persons working in the Rasulid administration, the descendants of the former South Arabian dynasties of the Sulayhids and Hamdanids and lastly the various tribes. ${ }^{32}$

Overall, Turfat al-Asha ăb comprises a precise framework to explicate the Rasulids' ethnic origins based on their genealogical lineage in association with the source of their political power, in counter-distinction to and over other tribes and groups in South Arabia. As a result it gives the Rasulids an unambiguous statement of their superior status in order to further provide another source of legitimacy for their rule over most of the region at the turn of the seventh/thirteenth century. But while there are allusions to the events that surround and encompass these relationships, such as the building and destruction of the Ma'rib dam, the path of migration away from South Arabia to the north and the Rasulid's return or the sequence of kingship within South Arabia, this genealogical work lacks a strong narrative about them. This project was taken up a century later when the dynasty was struggling to maintain an authoritative position in the region.

\section{The Narrative}

Al-Khazrajī wrote $A l-{ }^{`} U q \bar{u} d$ al-lu'lu'iyya fì tārìkh al-dawla al-Rasūliyya at the turn of the ninth/fifteenth century when the authority and territory of the Rasulids had been decreasing over the past century while incursions and rebellions against them were increasing. In response, $A l^{\circ} U q \bar{u} d$

\footnotetext{
${ }^{32}$ In the middle of his description of the other tribal lineages, he leaves a note which demonstrates his disdain for them and the minimal benefit of including them in the work, further pointing to the singular ideological message of support for the Rasulids that he wants to communicate in this work, instead of a broader record of the entire tribal community: 'When we considered mentioning the shaykhs and the disintegrating tribes and mentioning their children, it did not have much benefit, so we abstained from mentioning their children and their offspring, and [instead we only] wrote about the origin of their lineages so that something useful might be gained from this' (Al-Ashraf 'Umar, Turfat al-așhāb: 125).
}

- The Medieval History Journal, 21, 2 (2018): 380-399 
al-lu'lu'iyya takes on an extraordinary tone of ideological fervour to express a message that celebrates the glory and power of the Rasulids as evidenced in the historiographic reworking of events described in earlier more sober chronicles and the obituary summations of the characteristics and achievements of each sultan..$^{33}$ The main body of this work comprises annual chronicles for the first seven sultans of the Rasulid dynasty, as well as obituaries of notable individuals who passed away each year. But its celebratory tenor is set with an extended prologue that fleshes out the genealogical skeleton found in Turfat al-așhāb in order to bring further narrative depth to the story of the Rasulid origins in South Arabia and establish the dynasty as the rightful rulers of South Arabia. ${ }^{34}$ This origin story can be divided into three sections: (a) a mythological set-up about the inheritance of the roles of rulership in South Arabia and an annotated poem about the prophesised return of the Rasulids to re-establish local rule of the region by its tribal community, (b) a description of the exodus and journey of Ghassanid tribes out of South Arabia to Syria where they developed the new dynasty of the Jafnid kings, and (c) a narrative about how the first Rasulid leader emerged from the territory of the Turkoman tribes to work for the Abbasid Caliphate and how his son and grandsons rose to prominence in Egypt under the Ayyubids with whom they returned to South Arabia. Thus, in Al-'Uqüd al-lu'lu'iyya, al-Khazrajī twice inserts the Rasulids into this origin story, otherwise based on previous historiography of the Yemeni and wider Islamic traditions. Through this he demonstrates his command of the complex and circuitous way that the Rasulids both fit into the genealogical web of South Arabia and become the saviours of the region who re-establish local rule as the long-lost heirs of its ancient kings. The remaining parts of this article will highlight key portions of this multifaceted, ideological achievement to show how al-Khazrajī appropriated and manipulated previous aspects of South Arabian cultural memory to provide much-needed legitimacy for the Rasulid dynasty.

\footnotetext{
${ }^{33}$ This tone would especially be expected because al-Khazrajī's creation of this work was in close conjunction with Rasulid Sultan al-Ashraf Ismā'îl. Sometimes both individuals are noted as the authors of the larger world chronicles from which this dynastic chronicle emerges (Vallet, 'L'historiographie rasūlide': 97-99). But Al-'Uqūd al-lu'lu'iyya contains the obituary of al-Ashraf Ismā̄îl, thereby insinuating that al-Khazrajī may be attributed the final version of the work. For examples of its historiographic differences from earlier Rasulid chronicles, see Smith, 'Ayyubids and Rasulids'.

${ }^{34} \mathrm{Al}-\mathrm{Khazraj} \overline{1}$, Al-'Uqūd al-lu’lu’iyya: 35-63.
} 
The first section of the origin story starts with a recounting of the beginning of kingship in South Arabia. ${ }^{35}$ Its funerary setting is framed precisely to address the question of succession of power in South Arabia.

Saba' al-Akbar, when death was near, requested his two sons Himyar and Kahlān. He seated Hiimyar, being the older, on his right and Kahlān on his left. Then he requested the rest of his sons, cousins, and the elites of his people, and said to them: 'These two sons of mine - he on my right, indicating Himyar, and he on my left, indicating Kahlān — give to Himyar from my possession what is suitable for the right and give to Kahlān from my possession what is suitable for the left'. They said: 'That which is suitable for the right is the sword, whip, and pen; and that which is suitable for the left are the reins, shield, and bow' ${ }^{36}$

It is then explained that the implements for Himyar enable him to take on the characteristics of the greatest king (al-malik al-ac zim). As for Kahlān, it is asserted that:

The possessor of the reins steers the necks of the horses to drive away [others] from the kingdom; and with the shield he repels people upon encountering [them in battle]; and with the bow he reaches those who are hostile and those who are raiding [...] Those are only suitable for the protector of the dawla, standing up in its wars and blocking its frontiers. ${ }^{37}$

Essentially, this passage shows how, while Himyar may become the principle ruler over South Arabia, Kahlān will play the important role of safe-guarding it from intruders. Next al-Khazrajī states that while Himyar and his progeny took over the kingship until al-Ḥärith al-Rầish, Kahlān and his descendants took over the defence of the kingdom and its frontiers until 'Āmir ibn Ḥāritha al-Azdī, who lived in the same period. While these two were mentioned in Turfat al-așhāb, this work provides

\footnotetext{
${ }^{35}$ Although he does not directly cite his sources, it is clear that he is building upon the works of early medieval Yemeni authors, such as 'Abīd b. Sharya al-Jurhumī, Abū Muḥammad al-Ḥassan al-Hamdānī, Wahb b. Munabbih and Nashwā b. Sa'īd al-Hiimyarī, who contributed to and continually reformulated the 'Qahtanide Epic' tradition which comprises the tales about pre-Islamic prophets and kings of South Arabia (Pitrovsky, 'Al-Hamdānī and Qahtanide Epos').

${ }^{36}$ Al-Khazrajīi, Al-'Uqūd al-lu'lu'iyya: 35.

${ }^{37}$ Ibid.
}

- The Medieval History Journal, 21, 2 (2018): 380-399 
more background, context and parallelism between them to emphasise the greater significance of the divergence of their lineages.

After laying out these foundations of kingship and genealogy in South Arabia, al-Khazrajī then introduces the literary device of a prophetic poem in order to set up the rest of the origin story. Through it he clearly lays out the relationship of the Rasulids to the overall succession of rule in the region. He describes al-Hārith al-Rāish as a soothsayer who predicts and composes poetry about events before they occur, including a poem about 'his people and their renown until the end of time'. ${ }^{38} \mathrm{Al}$-Khazrajī goes on, first reciting this poem in its entirety and then providing a nearly line-by-line annotated version to elucidate its verses for the reader. ${ }^{39}$

The overall content of the poem describes the nature and sequence of kingship over South Arabia from the time of al-Hâarith al-Rầish to the Prophet Muhammad, denoted as 'al-Tihāmī'. It begins with lauding the South Arabian kings whose quality was as high as the tops of the clouds. But then it bemoans the spread of presumably the Ethiopians (al-asāwid) in South Arabia as a punishment of God. Here al-Khazrajī specifies their reign, including Aryāt, Abraha and his sons, lasted 72 years. Next the poem broadly describes the subsequent rulers to be 'from among us' but weak; however, al-Khazrajī does not provide any specific insight into who they may be. Instead the poem moves on to describe the appearance of the Prophet Muhammad and the Qurān, as well as the subsequent rule of the caliphs. ${ }^{40}$ At this point in the annotation, before moving onto the next verse of poetry, al-Khazrajī sets up the reader to understand that the poem will now be speaking about the appearance and capturing of Yemen by the kings of Ghassān. The poem itself then states that 'the sons of 'Ām will rule', which al-Khazrajī clarifies to mean 'Āmir b. Ḥārith b. Amri' al-Qays b. Tha'laba b. Ma'rib b. al-Azd b. al-Ghawth, whose name was

${ }^{38} \mathrm{Al}-\mathrm{Khazraj} \overline{1}$, Al-'Uqüd al-lu'lu'iyya: 36 . The word for soothsayer here is 'muhaddath', which is defined in the text as the one who speaks about the futures (mustaqbalat) of time.

${ }^{39} \mathrm{Al}-\mathrm{Khazraj} \overline{1}$, Al-' Uqū d al-lu'lu'iyya: 36-39.

${ }^{40}$ This sequence of rulership in South Arabia is reminiscent of a short dialogue attributed to Wahb b. Munabbih and found in various medieval historiographic works (e.g., al-Hamdānī, al-Iklīl: vol. 8: 180-81). It questions as to whom the region belongs and then goes through these same groups (the Himyar, Habasha and the Quraysh) but also includes the Persians which are not found in the poem in $A l_{-}{ }^{\prime} U q \bar{u} d$ al-lu'lu'iyya. 
cut off to fit into the metre of the poem. Finally, the poem states 'the banner of al-Manșūr will appear', which al-Khazrajī makes explicit that the sentence indicates the appearance of the first Rasulid Sultan al-Manșūr 'Umar, further adding that his independence in kingship over Yemen and the succession of his progeny continues up to that time.

Overall this prophetic poem may be seen as a counterpart to the list of kings in the Himyar genealogical section of Turfat al-aș $h \bar{a} b$ but not entirely as a replacement. It lacks many of the predecessor's details, including prominent groups of rulers from the most ancient period (e.g., the aqyāl and $t a b \bar{a} b i^{c} a$ ) to the later more well-documented eras (e.g., Dhū Nūwās and Sayf b. Dhī Yazan). These details, however, are clearly not important for al-Khazrajī's message. But rather his main focus is to underscore the most important segments and trends of Yemeni political history, especially the deterioration of its rule by locals, which only improved with the appearance of Islam and then the arrival of the Rasulids. The concentrated attention to the shape of this political upswing is then reemphasised in the last lines of this section, where al-Khazrajī makes his ideological motivations for the recitation of this poem abundantly clear.

I have explained this poem, which al-Ḥārith al-Rāàish said in a refined portion, and which I have entitled 'The Result of Tracing the Ancestry of the Banū al-Rasūl'. That is because [the poem] bore witness to the veracity of their lineages. Rarely does there exist evidence for the veracity of a lineage of one of the people as the veracity of this lineage. ${ }^{41}$

In the second section of the origin story, al-Khazrajī moves beyond the story of kingship within South Arabia and shifts focus to a narrative about the breaking of the Ma'rib dam which led to the emigration of various tribes from South Arabia, including the Ghassān. In this section, alKhazrajī extensively cites and quotes many historians and poets, such as the author al-Tījān ${ }^{42}$ al-Ișfahānī, al-'Asharī, Ibn Qutayba and al-Mas' ${ }^{\complement} \bar{u} \mathrm{i}$, to the extent that it mainly consists of an edited compilation of these other writers. Through these authors he narrates the commonly told story of the migration of tribes out of South Arabia and their resettlement in other parts

${ }^{41}$ Al-Khazrajīi, Al-'Uqūd al-lu'lu’iyya: 39.

${ }^{42}$ Although not specified in the text, this refers to the seventh/eighth-century Yemeni historian Wahb b. Munabbih who wrote Kitab al-tījān fì mulūk al-Himyar.

- The Medieval History Journal, 21, 2 (2018): 380-399 
of the Near East. It begins with the back story of the involvement of the descendants of 'Āmir ibn Ḥaritha al-Azdī, who appears only briefly in Turfat al-așhāb, in the maintenance of the Ma'rib dam and their subsequent abandonment of it because of a dream premonition about its destruction. After the breaking of the dam, the story follows the journey of this family in the context of the other tribes who had lived there as they dispersed across the Arabian Peninsula in various directions. After first migrating to the land of 'Akk and then Mecca, the descendants of this family led by Jafna b. 'Amr b. 'Āmir along with other tribes of Ghassān decided to emigrate to al-Shām (Syria) where they defeated the armies of Qayșar (i.e., the unnamed Eastern Roman ruler: Caesar) and were appointed as his deputies over the Arabs of al-Shām. At this point al-Khazrajī interjects the narrative to specify different aspects of Ghassanids that reinforce their South Arabian connections, including a recitation of their entire regnal line extending from the first king Māzin b. al-Azd to the sons of al-Ayham ${ }^{43}$ and stories about their time in South Arabia, such as the origin of their name. ${ }^{44}$ At the end of this section, the voice of al-Khazraji again returns to the narrative of the origin story, emphasising that 'the sons of Jabala b. al-Ayham are among the progeny of the kings of Yemen in the period of Islam', ${ }^{45}$ and then sets up the final section of the origin story which describes the return of these descendants of al-Azd to South Arabia.

The third section of the origin story begins with the recitation of the genealogical line of the patriarch of the Rasulid family:

The name of Rasūl was: Muḥammad, son of Hārūn, son of Abī al-Fatḥ, son of Yūhā, son of Rustam, and he is from the offspring of Jabala, son of Ayham, son of al-Ḥārith, son of Tha'laba, son of 'Amr, son of Jafna, son of 'Amr Muzayqiyā', son of 'Āmir Mā' al-Samā’, son of Haritha al-Ghițīf, son of Imrā’ al-Qays al-Bațrīq, son of Tha'laba al-Bahlūl, son of Māzin Zād al-Safar Qātil al-Jaw’, son of al-Azd, son of al-Ghawth, son of al-Nabt, son of Mālik, son of Zayd, son of Kahlān, son of Saba', son of Yashjub, son of Ya'rub, son of Qaḥțān. ${ }^{46}$

Its placement at this point in the story seems to serve as a type of narrative hinge which enables both a quick review from which it (and the lineage)

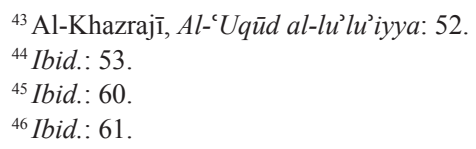


began and points towards the future of how it will return to South Arabia. There are some differences in the details from the genealogy found in Turfat al-așhāb, which may be expected due to the century that has passed between the two works. But what is more notable is that al-Khazrajī does not cite or mention the work of al-Ashraf 'Umar nor give any other indication from where this information comes.

Al-Khazraji then continues the origin story in this new phase by beginning with a direct explanation of the source of confusion regarding the ethnic origins of the Rasulids. He states that the children of Jabala $b$. Ayhām moved to the land of the Turkoman (bilād al-turkumān) where the most noble of the tribes by the name of Bịhak were living. ${ }^{47}$

They resided among [the Turkoman tribes], spoke their language, and became distant from the Arabs. Their communication with many people was cut off. Many people thought that they were from the Turkoman people, but they stuck to their genealogical lineages. So when a family of this group departed to Iraq, whoever knew them attributed their descent to Ghassān, but those who did not know them attributed it to the Turkoman people. ${ }^{48}$

In this passage al-Khazrajī clarifies that this group of descendants from the Ghassanids lived among the Turkoman tribes during their sojourn, but they maintained an endogamous purity that preserved their Arab descent. Furthermore, he emphasises that anyone who thought differently (including, presumably, Arabs in South Arabia) was merely ignorant of this separation. Al-Khazraji next tells of the appearance of the titular head of the Rasulids, Muhammad b. Hārūn, who was given the nickname of 'Rasūl' (meaning messenger in Arabic) when he began to work as a courier to Syria and Egypt for the Abbasid Caliphate. It is narrated that he and his family moved to Egypt, where they became so esteemed by the Ayyubids to the extent that they were offered South Arabia as their own land - and so, accompanying Turānshāh, Shams al-Dīn 'Alī b. Rasūl and his four sons returned to South Arabia. This story of the glorious homecoming ends with poetry ascribed to one of the sons of Shams al-Dinn, who describes the Rasulids in the same roles of defence that Kahlān was said to have

${ }^{47}$ It alternatively appears as Manjik in other works (Al-Khazrajī, Al-' $U q \bar{u} d$ al-lu'lu'iyya: 61, ft. 3).

${ }^{48} \mathrm{Al}-\mathrm{Khazraj} \overline{1}$, Al-'$U q \bar{u} d$ al-lu’lu’iyya: 61-62.

- The Medieval History Journal, 21, 2 (2018): 380-399 
undertaken: 'We are its protectors and we drive [others] away from it while wicked people eat away at its overabundance. ${ }^{39}$

\section{Conclusion}

Taken together this origin story communicated in the writing of alAshraf 'Umar and al-Khazrajī demonstrates how a powerful hybrid of historiographical forms may work together to take up local cultural memory and splice it to suit the political needs of an external force intruding from outside the region. While there is no direct evidence that there was a cooperative effort to provide different perspectives to the problem of origins (as al-Khazrajī does not mention al-Ashraf 'Umar in his own work), their similar political cause and perspective show the powerful impact engendered through the blending of various strands of knowledge to build a complex case for legitimacy based on both lines of genealogy and kingship. The argumentation of this work may appear too complicated or convoluted, but the dispersed and dynamic socio-political landscape of South Arabia in the late medieval period demanded such intricate reasoning in order to strive for both unity and dominance over it. Consequently, it was necessary to use such foundational memories based on ancient monuments (of both cultural and religious heritage) such as the Ma'rib dam and a genealogy of both North and South Arabia. It was only through this design of commemoration for the origins of the political community that it could be simultaneously reformed and subjugated.

\section{Declaration of Conflicting Interests}

The author declared no potential conflicts of interest with respect to the research, authorship and/or publication of this article.

\section{Funding}

The author disclosed receipt of the following financial support for the research, authorship and/or publication of this article. The research for this article was funded by the Austrian Science Fund (FWF): F42-G18 Visions of Community.

\footnotetext{
${ }^{49}$ Al-Khazrajīi, Al-'Uqūd al-lu’lu’iyya: 63.
} 


\section{References}

Al-Ashraf'Umar. 1949. Turfat al-așhāa fi má rifat al-ansāb, edited by Karl W. Zettersteen. Damascus: Mațba'at al-Taraqqī.

Al-Hamdānī, al-Ḥasan b. Aḥmad b. Ya'qūb. 2004. Al-Iklīl, vols. 1, 2, 8, 10, edited by Muhammad b. 'Alī al-Akwa'. Sanaa: Wizārat al-Thaqāfa wa-l-Siyāḥa.

Al-Khazrajī. 2009. Al-'uqūd al-lu'lu’iyya fì tārīkh al-dawla al-Rasūliyya, edited by 'Abd Allāh Muhammad al-Hibshī, 2 vols. Sanaa: Maktabat al-Irshād.

Al-Muz̦affar. 1989. Al-mukhtara' fì funūn al-șnac, edited by 'Isā Șālihiiyya. Kuwait: Mu’assasat al-Shirāe al-'Arabī.

Anonymous. 2003 and 2005. Nūr al-ma'āriffì nuzum wa-qawānīn wa-a'rāf al-Yaman fì al'ahd al-muzaffarī al-wārif, edited by Muḥammad 'Abd al-Rahīm Jāzim, Lumière de la Connaissance. Règles, Lois et Coutumes du Yémen sous le Règne du Sultan Rasoulide alMuzaffar, 2 vols. Sanaa: Centre Français d'Archéologie et de Sciences Sociales de Sanaa.

Assmann, Jan. 2011. Cultural Memory and Early Civilization: Writing, Remembrance, and Political Imagination. Cambridge: Cambridge University Press.

Baker, Christine D. 2015. 'The Lost Origins of the Daylamites: The Construction of a New Ethnic Legacy for the Buyids', in The Routledge Handbook of Identity and the Environment in the Classical and Medieval Worlds, edited by Rebecca Futo Kennedy and Molly Jones-Lewis. Abingdon: Routledge: 281-95.

Bates, Michael. 1975. Yemen and Its Conquest by the Ayyubids of Egypt (A.D. 1137-1202). Unpublished PhD Thesis: Department of Near Eastern Languages and Civilizations, University of Chicago.

Golden, Peter B., Tibor Halasi-Kun, Louis Ligeti, and Edmund Schütz (eds). 2000. The King's Dictionary: The Rasûlid Hexaglot: Fourteenth Century Vocabularies in Arabic, Persian, Turkic, Greek, Armenian and Mongol. Leiden: Brill.

Ibn Ḥātim. 1974. Kitāb al-simṭ al-ghālī al-thaman fì akhbār al-mulūk min al-ghuzz bil-Yaman. Edited by Rex Smith, The Ayyūbids and Early Rasūlids in the Yemen (567694/1173-1295) Volume 1: a critical edition of Kitāb al-Simt al-Ghālī al-Thaman fì Akhbār al-Mulūk min al-Ghuzz bi'l-Yaman by Badr al-Dīn Muhammad b. Hātim al-Yāmī al-Hamdānī with list of contents and index of personal names. London: Messrs Luzac and Company Ltd.

Iliushina, Milana Yu. 2014. 'The Origins of the Circassian Mamluks: A Subject of MythMaking', Basic Research Program Working Papers 64. Moscow: National Research University Higher School of Economics: 1-13.

Mahoney, Daniel. 2016. 'The Political Agency of Kurds as an Ethnic Group in Late Medieval South Arabia', Medieval Worlds, vol. 3: 146-57.

Pitrovsky, Michael. 1986. 'Al-Hamdānī and Qahtanide Epos', in al-Hamdānī: lisānn alYaman, edited by Yūsuf Muḥammad 'Abd Allāh. Sanaa: University of Sanaa: 159-67.

Shatzmiller, Maya. 2000. The Berbers and the Islamic State: The Marinid Experience in Pre-Protectorate Morocco. Princeton, NJ: Marcus Weiner Publishers.

Smith, G. Rex. 1969. 'The Ayyubids and Rasulids: The Transfer of Power in 7th/13th Century Yemen', Islamic Culture, vol. 43: 175-88.

1978. The Ayyūbids and Early Rasūlids in the Yemen (567-694/1173-1295). Volume

2: A Study of Ibn Hatim's Kitab al-Simt Including Glossary, Geographical and Tribal Indices and Map. London: Luzac and Company Ltd.

- The Medieval History Journal, 21, 2 (2018): 380-399 
Szombathy, Zoltan. 2003. The Roots of Arabic Genealogy: A Study in Historical Anthropology. Piliscsaba: Avicenna Institute of Middle Eastern Studies.

'Umāra. 1892. Tārīkh al-Yaman, edited and translated by Henry Cassels Kay, Yaman: Its Medieval History. London: Edward Arnold.

Vallet, Éric. 2006. 'L'historiographie rasūlide (Yémen, VIIe-IXe/XIIIe-XVe siècle)', Studia Islamica, vol. 102/103: 35-69. 